\title{
Analysis of the Quality Problem of Scientific School in the Higher Russian Technical Education by the Graduates and Professors of MSTU "STANKIN"
}

\author{
Marianna V. Mikhaylova ${ }^{1, *}$ and Marina A. Revina ${ }^{1}$ \\ ${ }^{1}$ Moscow State Technological University "STANKIN", Department of philosophy, RU-127055, Moscow, Russia
}

\begin{abstract}
Higher education reforms can give Russian higher technical schools significant advantages, but at the same time they hide serious dangers. As a result of these reforms, the modern higher technical school in Russia is facing many problems. Firstly, the quality problem: technical education in Russia has always been at a fairly high level, due to its integrity and fundamental nature, so the feasibility of reforms often raises questions. Secondly, the organizational problem: the natural process for higher education in the modernization of education and the consolidation of knowledge in itself is quite complicated. The combination of the modernization process and reform is causing considerable resistance and questions, since it seems insufficiently thought out. Thirdly, the problem of training a creative engineer for the society of the future does not find a solution, because the process of training a specialist is becoming more and more mechanistic. Previously, engineering students within five and a half years had the opportunity to join the scientific community, thanks to the presence of individual work and direct communication with scientists of different generations. Modern communication between professor and student is largely carried out through the electronic environment, so they are more fragmented and mosaic. The lack of real practice in enterprises leads to the fact that students do not receive a live request from production for their creativity. In such conditions, the training of creative technicians is very difficult. It is advisable to reform higher technical education in the light of these problems, so that in the final, Russian education will benefit from them, while maintaining its identity.
\end{abstract}

\section{Introduction}

The most powerful integrative tendencies of the general process of globalization became the reason why Russia signed the Bologna Agreement in 2003. For the last decade, Russian higher education has been living under the Bologna agreement system. Of course, today the process of reforming Russian higher education needs analysis and adjustment. It is necessary to clarify the goals of the reform, based on the potential of Russian technical education in the global educational environment, as well as improving the means and technologies to achieve the goals.

The main goal of the Bologna Agreement was the creation of a single European space of higher education through the convergence and harmonization of their educational systems. [1] And this step was supposed to contribute to the modernization and development of higher professional education in Russia and lead to the construction of an educational system similar to the educational systems of European countries. The question of which system was better, why, assessment criteria, why exactly, we will not touch, but consider this new system for the Russian school from the perspective of functionality.
The positive aspects of the Bologna process are declared:

1.increase in the availability of higher education,

2. increased mobility of students and teachers,

3. great variability in the possibilities of continuing education (master's program in another university or in another specialty),

4. orientation of academic degrees and assigned qualifications to the needs of the labor market through the introduction of a competency-based approach.

Russia is gradually integrating into the international educational space, universities are increasingly appearing in international rankings. Representatives of domestic and European universities began to "speak the same language" when coordinating curricula, jointly developing bilingual study programs and double diploma programs. Also, the Bologna system involves the development of educational standards and criteria for assessing the quality of education, which should make it easy to determine the level of training of university graduates and simplify their employment. [2]

With a reasonable transition to the Bologna education system, universities should prepare graduates who are initially focused on practical activities, are mobile, in

e-mail: mari.mikhaylova@list.ru 
demand by employers and are competitive in the European labor market. [3]

Of the main provisions of the Bologna Declaration, Russia has fully implemented the transition to a multilevel system of higher education and the introduction of bachelor's and master's degrees, for which you need to accumulate a certain number of credit units (ECTS). According to the latest Russian legislation, there are three levels of higher education:

- Higher Education - Bachelor;

- Higher education - specialty, magistracy;

- Higher education - training of highly qualified personnel.

For the rest, talking about the final implementation of the principles of the Bologna process is premature. There are obvious difficulties the transition to the Bologna system is associated with. First of all, there is a risk of leveling the valuable national experience accumulated over the entire history of domestic higher education, and technical specialties are unique in its fundamentality and educational thoughtfulness. In the report "Reflections on the Bologna Process" V.A. Sadovnichy calls two fundamental principles of Russian higher education - this is fundamental and mentoring: “... Russian education is always fueled by fundamental science. For us, the question has never been: is science needed at universities? (And such issues are discussed at international forums.) We have always believed: science is part of education, moreover, its foundation. One of the strengths of our education is that young students begin to engage in science under the guidance of scientists. From the very beginning, students become part of a scientific school and get the opportunity to communicate with scientists of different generations and ages.” [4]

Enhancing academic mobility of students has a downside: Russian universities can turn into a supplier of qualified personnel for economically more developed countries. And this phenomenon is an inevitable companion of the internationalization of education, therefore it is necessary to create economic and social conditions to prevent the brain drain of the domestic scientific and technological elite from the country. In addition, the task of making Russian education completely "convertible" within the European space has not yet been completed: for European students, Russian universities are not of particular interest, and in the European labor market, diplomas of graduates of our educational institutions (with the exception of several leading universities) are few in demand. Another negative point is that, according to the Bologna agreement, we must prepare graduates of the "sought after in the European labor market”, that is, firstly, such a formulation gives rise to the idea of "peripherally" of Russian higher education in relation to European education, and second, the very scale of Russia implies that the graduate has a more widely specialized fundamental base, at least in technical specialties.

That is why a number of specialists express serious concern about the decline in the level of higher education due to its orientation towards the training of rather narrow specialists, to the detriment of the fundamental training that develops analytical and critical thinking. For example, according to Mikhail Anipkin, a doctor of sociological sciences and professor of sociology at Volgograd State University, Essex University, "in reality, no transition to this system has occurred. All the similarities with the real Bologna system ends with the creation of a three-level education. The teaching staff, instead of science and the preparation and processing of lectures and seminars, writes unnecessary teaching and learning complexes, prepares mountains of useless reports. All the activities of a university teacher today are reduced to the production of tons of waste paper, which has nothing to do with science or teaching. This is not the Bologna system, but an absolutely incomprehensible mutant that does not resemble either the old Soviet or Western systems.” [5]

Moreover, the greatest concern of the faculty is the quality of the graduate, that is, the content of education, its sufficiency so that the graduate can be called an engineer, because in Russian higher schools they have always been engaged in the formation of engineering thinking with a basic set of necessary knowledge for further practical activities, and now this is a set of competencies.

And finally, linking and bringing one educational system to another is a technical issue that satisfies the goals of the Bologna Agreement, and the goals of the Russian higher school consist of state interests, trends in the development of science and the humanization of society. [6] The main idea of Humanism in pedagogy is the value of a creative person in the world, its purpose and goals of self-realization. Education in classical Humanism is rather a challenge to reaching the highest points of the culture of civilization, the aristocracy of human nature and is not perceived as a given limited by historical and cultural circumstances. "Humanism is a form of ontic value and historical ability of a natural identity, person and society."[7] In all educational systems of modern pedagogy, the theme of humanization is blurred and incomprehensible.

The problem is also the lack of awareness of students, teachers, university administrations about the situation in domestic and European education, the goals and objectives of the Bologna process (or education reforms). But if education stakeholders (students, employers, trade unions, civil society) do not actively participate in this process, the education system will not transform, or it will be formal. [8]

\section{Analytical part}

In order to study the views of graduate students and the academic higher technical school representatives about the state of education at the present stage of the implementation of various transformation processes, a pilot study was conducted on the basis of MSTU Stankin, in which 84 graduate students and 26 professors (13 candidates and 13 doctors of sciences) took part. Respondents were asked 11 open-ended questions, to which written answers were received among graduate students, and interviews were conducted among faculty members on the same issues. To analyze the results, the 
method of content analysis and factor analysis were used.

\subsection{Satisfaction}

According to the survey, professors (76.9\%) and more than half (61.9\%) of graduate students are mostly dissatisfied with higher education reforms (see Fig. 1). $38.1 \%$ of graduate students were satisfied and "satisfied with reservations", professors did not show satisfaction, but $23.1 \%$ were "satisfied with reservations". The difference is understandable due to the fact that professors are more involved in the educational process and those changes that occur are perceived more sensitively. This, however, does not negate the general rejection of the situation in higher education.

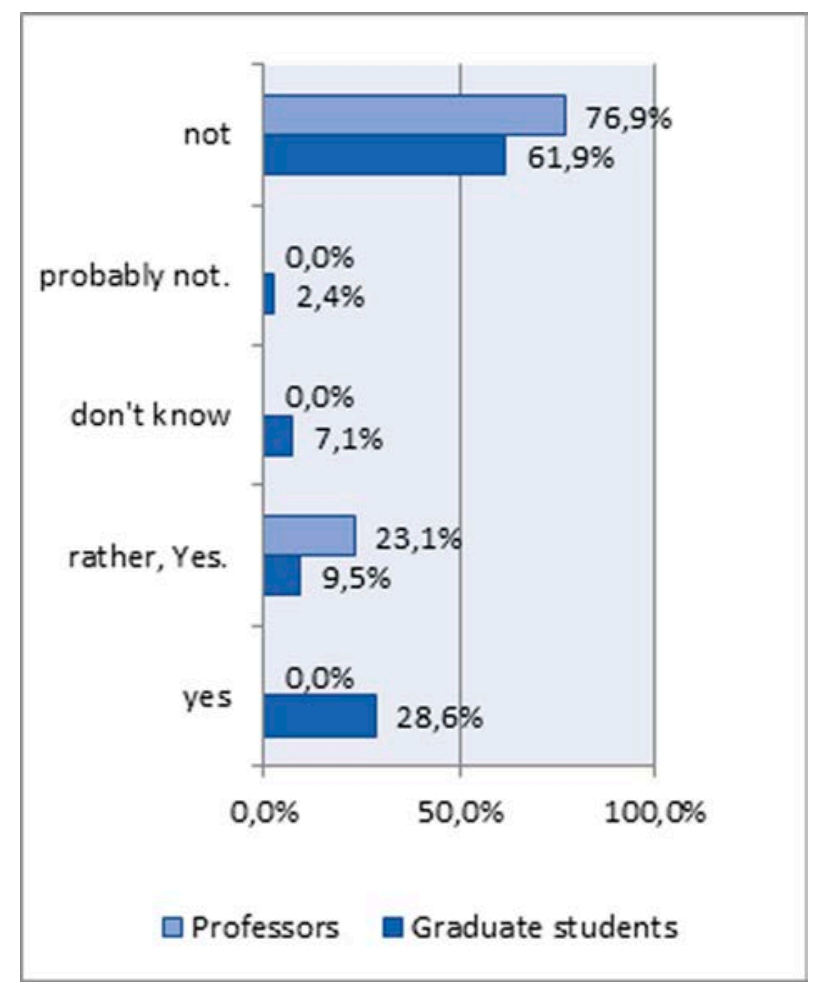

Fig. 1. Respondent Satisfaction with Higher Education Reforms.

\subsection{Understandability}

About half (50\%) of graduate students and $46.2 \%$ of professors believe that the objectives of the reform are not clear to the staff, and it is not because they do not know about them, but because the cost of efforts to comply with the Bologna agreement is much higher than the benefits received so far. Or, perhaps, for 70 years Russia has lived by the principle of "ideological ideality," and now the national benefit is not clear enough. Lack of understanding, as a rule, causes a lot of non-optimistic interpretations, fears of losing the achievements that the Russian scientific school had in the field of personnel training and, as a result, some resistance.

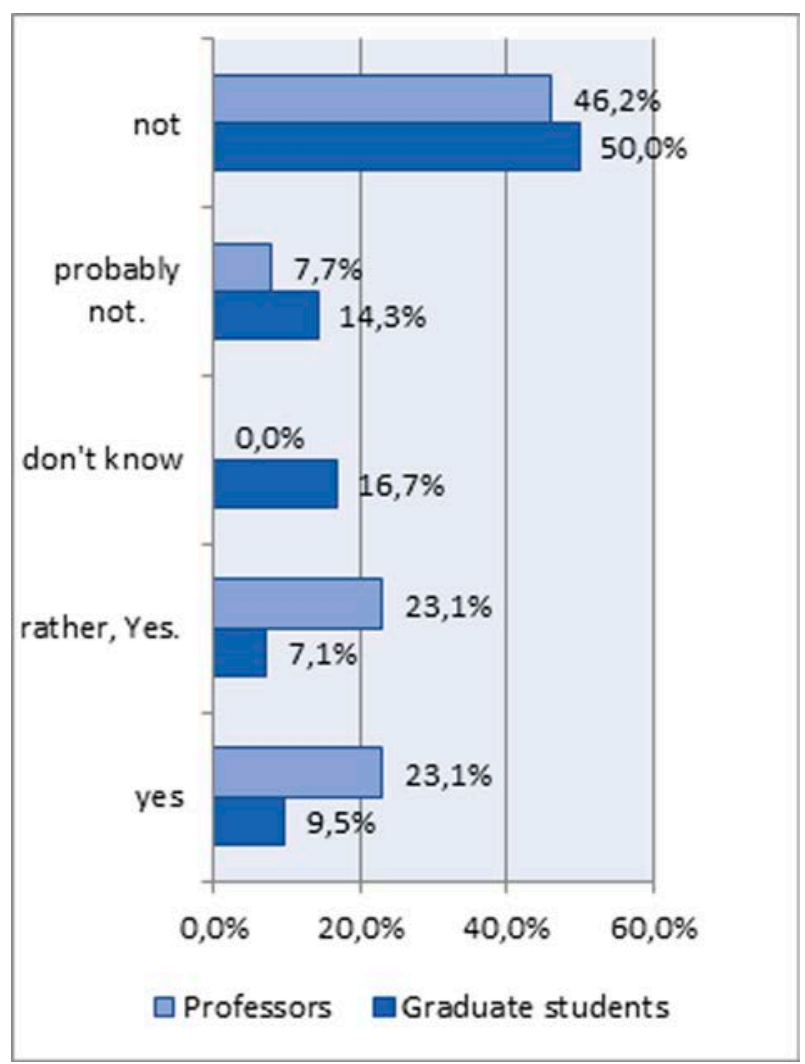

Fig. 2. Respondents' opinions on the comprehensibility of the goals of the reform of the faculty.

\subsection{Relevance of goals to results}

Since the vast majority of graduate students (76.2\%) and more than half of professors (61.5\%) noted the lack of positive results, which can be explained in this group by the fact that progressive changes in intellectual growth in higher technical schools in the field of science do not occur due to changes . That is, the respondents in our group do not see a qualitative improvement in the training of young specialists graduated from the university.

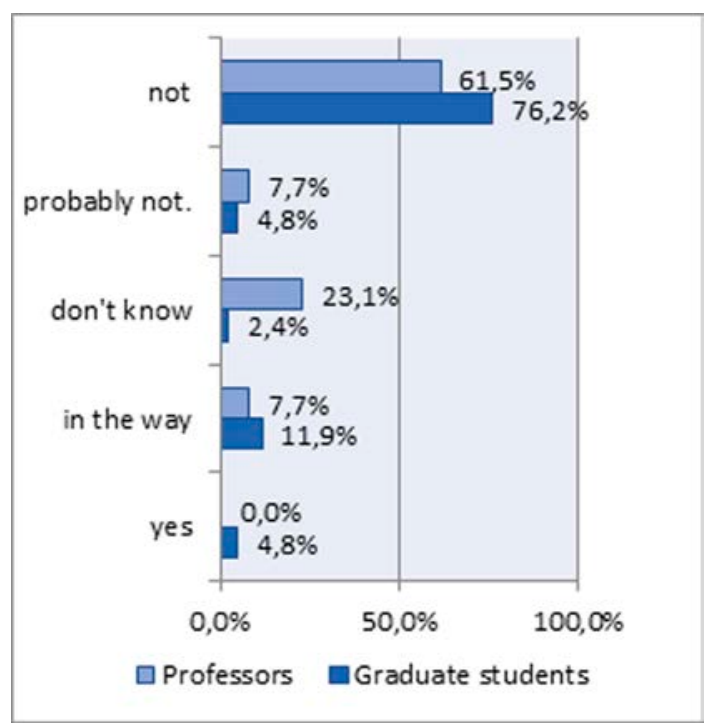

Fig. 3. Respondents' opinions on whether the achieved results are consistent with the goals set by the reforms. 


\subsection{Sufficiency of information}

On the issue of sufficiency of information on reforms, there is a difference in the opinions of professors and graduate students. Only $23 \%$ of professors believe that there is little information, with $66.7 \%$ of graduate students. At the same time, the issue of the sufficiency of information also shows the degree of involvement or interest in this subject: graduate students do not yet fully possess the independence of scientific thinking, and professors feel increased control, devaluation of the significance of higher education, loss of status of a professor's profession, the transformation of education into a service, which greatly reduces level of selfresponsibility.

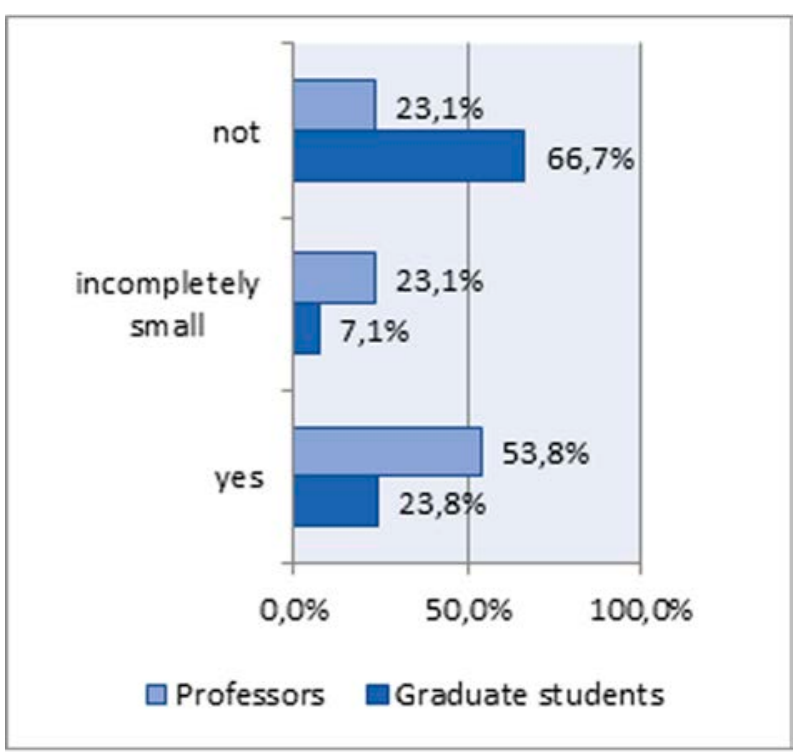

Fig. 4. Respondents' opinions on the adequacy of information on higher education reforms.

\subsection{The image of a graduate of a technical university in terms of training}

The image of a graduate of a technical university gives an idea of what set of qualities young specialist theoretically should have to become a good or welltrained expert before entering his professional sphere. Given the fact that the problem was open, the responses of the respondents were grouped into several categories. Most often, professional knowledge was noted: deep fundamental and applied, high qualification, knowledge of modern technologies, wide professionalism. Almost every professor (92.3\%) and most part of graduate students (77.8\%) consider a high level of professional knowledge to be the first necessary component in the image of a graduate. Also, half of professors (53.8\%) and one third of graduate students (30.6\%) consider that developed mobile intelligence, erudition and the ability to acquire knowledge are necessary qualities of a future engineer.

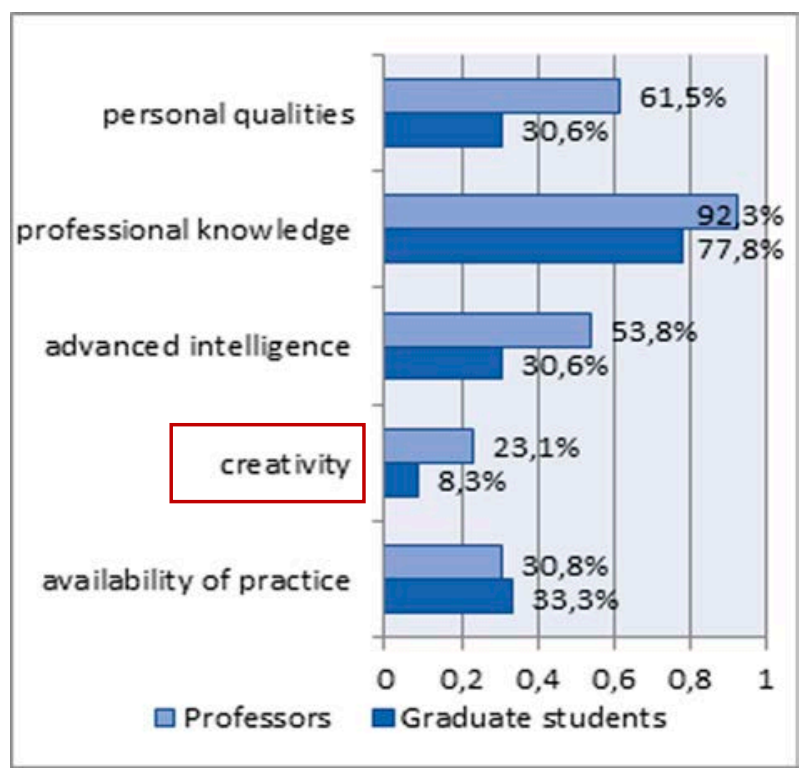

Fig. 5. Image of a graduate of MSTU Stankin from the point of view of respondents.

Significant differences can be observed in the category of personal qualities, which includes the following characteristics: decent, psychologically stable, able to work in a team, motivated, active, has life skill does not give in, etc. Considering that the average age of the professors surveyed is about 45 years (that is, professors with a minimum of 7-10 years of experience, at least $50 \%$ of the doctors of science) were intentionally selected, their image of a graduate has a more realistic perspective in terms of time, from the point of view of professional success in the future or "survival." Therefore, personal qualities are in second place after professional ones, in contrast to graduate students for whom this is third place. One third of professors and graduate students note the necessity of practice for the professional development of a specialist. We would like to note that professors were three times more likely to talk about the creative component of the graduate's image than graduate students, although this component of the image moved into the last place. Among the answers were: both the ability to invent - creativity, and the need to start using the achievements of heuristic educational technology in the educational process [9] [10], which, is seemingly now included in the program in the form of varied disciplines, but actually does not work in the form that, e.g. is used in Japanese universities, we need a specialist who can creatively solve specific technological problems at the country level. And special courses to choose from are needed, there should be more of them to ensure diversity, according to professors, as well as manual design, which is almost gone.

\subsection{Subjective attitude to the preparation of the graduate}

Subjective assessments for training a graduate of a technical university given by graduate students and professors had qualitative differences. Most graduate 
students note a high theoretical level of training and its fundamental nature. However, also, the majority (63.2\%) noted the absence or insufficiency of real practice in enterprises. Unfortunately, strong industrial interacting with factories and research institutes that existed Soviet Union today, for many reasons, are only being established. And I would also like to note that the problem of the lack of practical experience of a young specialist of a university graduate is a normal phenomenon - a situation where a university graduates a finished worker - this means that this university is that plant. Interviews with graduate students who got a job in their specialty or who came from other universities to specialize in their profile, as a rule, appreciate their education and are proud of it. I would like to note that only $5.3 \%$ of graduate students noted the creative component of the training, despite the fact that they all have either a specialty or a master's degree behind, which implies competencies related to creativity. We also noted shortcomings, conventionally designated as "motivation - the level of teaching", such statements as: it is necessary to motivate students more, incorrect teaching, a high level of undergraduate studies, Master's course does not make sense, some knowledge is outdated, it is necessary to increase the level of complexity. Stankin has a great potential, but you need to look for new ways of realizing it. Summarizing: an excellent base, not enough practice, and the last kind of challenge: "make it more complicate - we are not weak."

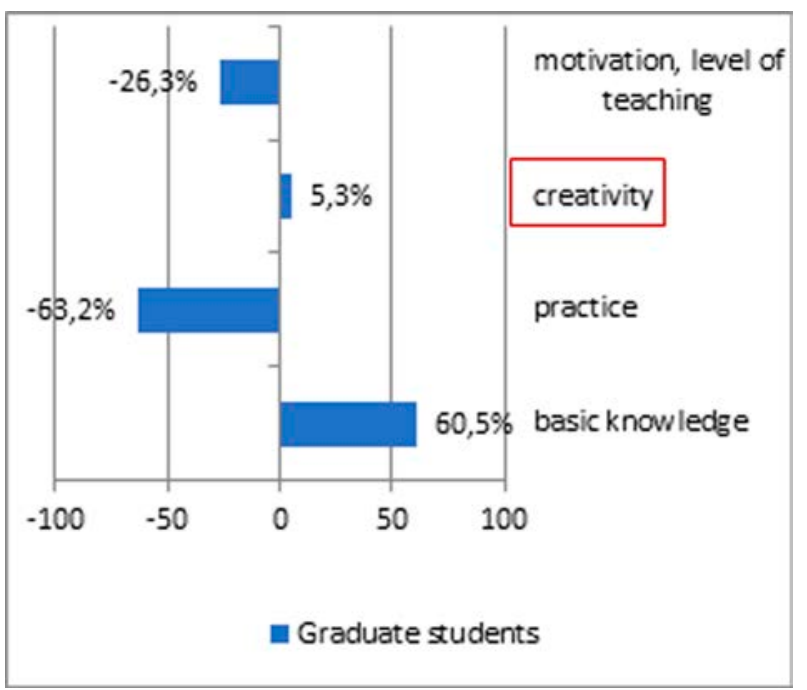

Fig. 6. Subjective opinions of graduate students about the level of training of a graduate of MSTU Stankin.

The subjective opinions of professors about the training a graduate of a technical university can be summarized as follows: thanks to the Unified State Examination, the foundation began to suffer during the preparation of an engineer, namely the formation of engineering thinking - Engineer Forma Mentis, since freshmen who came from school need to be taught how to understand the ideas and phenomena - in other words it is extremely necessary to increase the number of hours for natural sciences; due to the fact that the two-stage system does not give enough practice and basic knowledge at each stage of its way, although according to the plan of practice it is enough, but it is often formal and not efficient, as students need more professionalism; very good training compared to other technical universities (the opinion of doctors of technical sciences with experience in inter-university work), but the practice is not supported by real work, because of this the image of education changes for the worse ; we need various specialized courses to choose from, return manual design so as not to lose a good theoretical design base. There is not enough supervision; those who really study have a very good level of knowledge. Summarizing: an excellent base, but its formation is very difficult, the educational process must be strengthened or become more complicated with the help of special courses, internships and practice. But it is also possible to note such a point that studying at the university is now being reformed, the amount of knowledge that a student have to learn has increased greatly, as well as the requirements for training, and the time for studying has remained the same or decreased, which can lead to superficiality - this is a dilemma.

\subsection{Must Stankin's Master be a specialist in a wide or narrow profile?}

Despite the fact that educational standards and curricula have long been prescribed by a two-level system, the problem of filling the bachelor's and master's degrees with knowledge is still not understood and disturbs, most of the teaching staff. In most technical universities that trained engineers, the reaction to the situation is the following: an engineer must have a definite and sufficient knowledge base, therefore, it is necessary in the period of four years realize the program of five and a half years plus summer training. And it turned out to be practically hard to do, but a master's program is not a graduate school, it is the sphere that often requires new deep theoretical knowledge, but it has not yet been formalized and systematized. It is easier to carry out fragmentary narrow training. But it results in a failure in acquiring knowledge.

If we consider the data obtained, it is noticeable that graduate students are more willing to consider master's programs to be narrow-profile, although $23.8 \%$ of responding graduate students believe that a broad profile opens up the possibility of an interdisciplinary approach and the university level of training is still a worldview level and breadth of horizons.

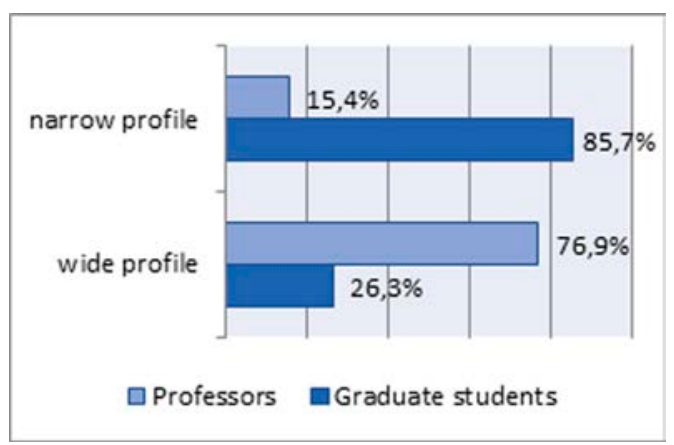

Fig. 7. Opinion of respondents about master's training. 
Among the professors, the opinion is more widespread that the master's program should have a deeper and wider level of theoretical training, since it is connected with the formation of scientific thinking and must also correspond to the specifics and scale of Russia, that is, the undergraduate must then be integrated into any process, and the narrowness of specialization may limit it. And there are opinions that the evening form kills the master's program, as the level of knowledge and the status of education decreases and the opinion that a narrow specialist will not be enough for a long time (given the increase in life expectancy and professional career).

\subsection{The main goals of higher education from the point of view of respondents}

Among graduate students, the answers to the question about the goals of higher education are distributed approximately as follows: in the first place is vocational training (broad-minded, fundamental, practice), in the second place is the ability to learn and find knowledge, in the third is the training of qualified personnel for the country and only in fourth place graduate students put the training of a creative specialist, despite the fact that for their level of education the development of creativity is extremely relevant . Opinions were distributed among the professors in a slightly different way: the first two places were taken by opinions on the preparation of a professional, who knows how to learn and find knowledge, in the third place, the professors put the task of identifying new discoveries and passing them on to future generations, but also training a creative specialist was in fourth place of importance. It is also significant that professors of higher school note the importance of forming such qualities of the personality of a future specialist as ethics, decency, patriotism, while graduate students do not consider such goals.

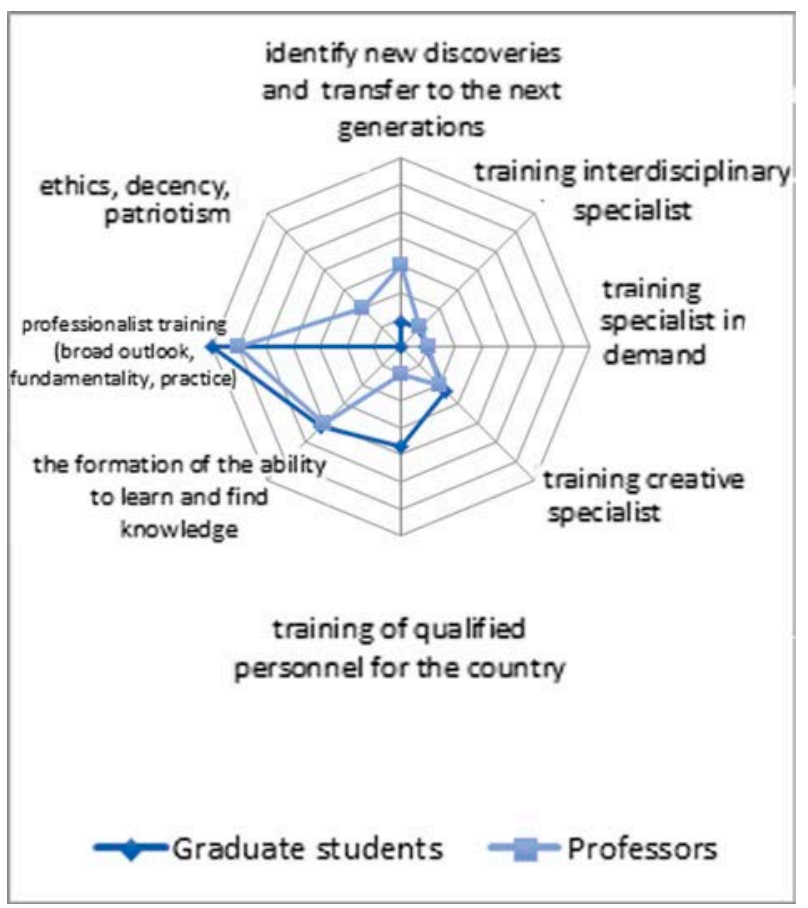

Fig. 8. Respondents' opinions on the goals of higher education.

\subsection{What should the humanization of higher technical education practically be expressed in?}

The issue of the humanization of higher education should reflect the respondents' ideas about how the idea of humanism is reflected in a technical scientific school, in the personality of an engineer. It should be noted that this question caused great difficulties for a group of graduate students and about half of the respondents did not answer it, while professors answered it with pleasure. The answers were grouped according to several factors for further analysis: postgraduate students by humanity in the broad sense understand the orientation of education towards the person and for the benefit of the person, the inclusion of disciplines related to art in the educational process, professors by humanity understand self-improvement of a person, ethics, philosophy, decency and intelligence. The practical expression of the humanization of higher education by graduate students is seen in closer contact with the faculty, tolerance, the possibility of variably more flexible education, in-depth career guidance and accessibility. Professors focus more on linguistic freedom and literacy, as well as communication skills. Despite the fact that interesting substantive opinions were expressed in both groups, creativity was ranked fourth.

Table 1. Monitoring of respondents' perceptions about the humanization of higher education.

\begin{tabular}{|c|c|}
\hline Graduate students & Professors \\
\hline $\begin{array}{l}\text { 1. found difficulty } \\
\text { replying. } \\
54,8 \%\end{array}$ & $\begin{array}{l}\text { 1. found difficulty in } \\
\text { replying. } \\
6,7 \%\end{array}$ \\
\hline 2. Humanity in a broad & 2. Humanity in the broad \\
\hline
\end{tabular}




\begin{tabular}{|c|c|}
\hline $\begin{array}{l}\text { sense: orientation on a } \\
\text { person, the inclusion of art } \\
\text { in the cycle of disciplines, } \\
\text { everything created by an } \\
\text { engineer should be useful } \\
\text { for human. } \\
16,7 \%\end{array}$ & $\begin{array}{l}\text { sense: self-improvement, } \\
\text { more ethics, discussion of a } \\
\text { circle of questions about the } \\
\text { postulates of philosophy, } \\
\text { transhuman ethics, decency, } \\
\text { intelligent personality, } \\
\text { everything created by an } \\
\text { engineer should be useful } \\
\text { for human. } \\
33,3 \%\end{array}$ \\
\hline $\begin{array}{l}\text { 3. Practically: } \\
\text { communication with the } \\
\text { prifessors, tolerance, } \\
\text { blurring of borders, } \\
\text { variability, in-depth career } \\
\text { guidance, accessibility. } \\
14,3 \%\end{array}$ & $\begin{array}{l}\text { 3. Practically: learn } \\
\text { Russian and foreign } \\
\text { languages, communication } \\
\text { skills, teamwork, } \\
\text { variability, in-depth career } \\
\text { guidance, accessibility. } \\
13,3 \%\end{array}$ \\
\hline $\begin{array}{l}\text { 4. Creativity } \\
4,8 \%\end{array}$ & $\begin{array}{l}\text { 4. Creativity. } \\
13,3 \%\end{array}$ \\
\hline $\begin{array}{l}\text { 5. Competence of } \\
\text { professors. } \\
4,8 \%\end{array}$ & $\begin{array}{l}\text { 5. More freedom in teaching } \\
\text { disciplines and correction } \\
\text { plans. } \\
13,3 \%\end{array}$ \\
\hline $\begin{array}{l}\text { 6. Humanization is not } \\
\text { related to higher education. } \\
4,8 \%\end{array}$ & $\begin{array}{l}\text { 6. Humanization is not } \\
\text { related to higher education. } \\
0 \%\end{array}$ \\
\hline $\begin{array}{l}\text { 7. Consideration of the } \\
\text { human factor in technical } \\
\text { education. } \\
2,4 \%\end{array}$ & $\begin{array}{l}\text { 7. Consideration of the } \\
\text { human factor in technical } \\
\text { education. } \\
6,7 \%\end{array}$ \\
\hline $\begin{array}{l}\text { 8. Patriotism, citizenship. } \\
0 \%\end{array}$ & $\begin{array}{l}\text { 8. Patriotism } \\
13,3 \%\end{array}$ \\
\hline
\end{tabular}

\subsection{The need for humanities at a technical university}

According to $96 \%$ of respondents, humanitarian disciplines are necessary at a technical university, however, the training program cannot be expanded and it is extremely difficult to place additional disciplines in the curriculum, but it is necessary in the case of a humanistic orientation of a higher technical school. Since this makes it possible to form thinking that has logics and methods of cognition in different sciences and is capable of creativity.

Table 2. Basic human qualities of an engineer through the eyes of respondents.

\begin{tabular}{|l|l|}
\hline $\begin{array}{l}\text { Core values called } \\
\text { graduate students }\end{array}$ & $\begin{array}{l}\text { Core values called by } \\
\text { professors }\end{array}$ \\
\hline Integrity 21,4\% & Integrity 38,5\% \\
\hline Responsibility 21,4\% & Curiosity 30,8\% \\
\hline $\begin{array}{l}\text { partnership (teamwork, } \\
\text { mutual assistance, } \\
\text { friendship) } 16,7 \%\end{array}$ & $\begin{array}{l}\text { love for the motherland, } \\
\text { family, friendship 23,1\% }\end{array}$ \\
\hline Creativity 11,9\% & Humanity 23,1\% \\
\hline $\begin{array}{l}\text { Enjoy their work - make } \\
\text { a difference 9,5\% }\end{array}$ & Responsibility 23,1\% \\
\hline Diligence 9,5\% & $\begin{array}{l}\text { Enjoy their work - make a } \\
\text { difference 15,4\% }\end{array}$ \\
\hline Curiosity 9,5\% & $\begin{array}{l}\text { Partnership (teamwork, } \\
\text { mutual assistance, } \\
\text { friendship) 15,4\% }\end{array}$ \\
\hline
\end{tabular}

\begin{tabular}{|l|l|}
\hline Tolerance 9,5\% & $\begin{array}{l}\text { Decision-making ability } \\
7,7 \%\end{array}$ \\
\hline Humanity 7,1\% & Tolerance 7,7\% \\
\hline Communicability 7,1\% & \\
\hline $\begin{array}{l}\text { Found difficulty in } \\
\text { replying 28,6\% }\end{array}$ & \\
\hline
\end{tabular}

\subsection{Basic human values of a graduate of a technical university.}

The question of what basic human values should be formed as a result of training an engineer was also open and should determine the ethical value of a design engineer. As a result of the analysis, all answers were grouped into separate blocks (table 2). So, it should be noted that this question caused less difficulty in the group of graduate students than the question of the humanization of higher education, only about a third of the respondents either missed the answer, or their answer was evasive. The listed qualities are eloquent in themselves and cause respect. Decency first, apparently, implies not only generally accepted ethics or scientific ethics, but also coherence and the presence of intrapersonal principles. However, it is worth noting that creativity again is put on fourth place.

\section{Conclusion}

As a conclusion, we would like to note that the processes of transformation of higher education are extremely painfully experienced in society, partly because education is part of the national culture and is crucial for life, it covers all sectors of the population, almost every family includes those involved in the educational process both directly and indirectly through those who study. But higher education will always change, it is inevitable, to paraphrase V. Frankl, we can say that each time has its own needs and each time needs its own form of pedagogy. However, this cannot mean either a decrease in the level of education of graduates, or the absence of progressive dynamics favorable to the Russian higher technical school associated with leveling the achievements and achievements of the domestic educational system. A creative breakthrough in the field of basic research can be made on the basis of a solid theoretical education and humanization of higher education, which consists in training a creative specialist.

This work was carried out using equipment provided by the Center of Collective Use of MSUT "STANKIN".

\section{References}

1. H. Coates, Assessment of Learning // The European Higher Education Area: Between Critical Reflection and Future Policies (Springer Cham, 399-413, 2015) 
2. European Commission/EACEA/Eurydice, 2018, The European Higher Education Area in 2018: Bologna Process Implementation Report (Luxembourg, Publications Office of the European Union). http://bit.ly/2u785Z9 (accessed 20/11/2019).

3. L.E. Egorova, O.E. Kondratyev, P.V. Roslyakov, G.V. Shvedov, Science and Education: Scientific publication, (S02), 6-6 (2014) [in Russian] ISSN 1994-0408

4. V.A. Sadovnichy, "Reflections on the Bologna Process", report of the rector of Moscow State University named after M.V. Lomonosov, Academician of the Russian Academy of Sciences, Professor V.A. Sadovnichy at the II International Seminar "Russia and the European Higher Education Area: Plans and Prospects after the Berlin Conference" October 29-30, SPbSU, (2003) [in Russian]

5. A. Koroleva, Bologna system - losses and achievements // IZ.RU: Izvestia newspaper website. 2017. URL: https://iz.ru/news/675017 (accessed date: 09/09/2019)

6. M.V. Mikhaylova, Vestnik MSTU «STANKIN» 3(46), 147-150 (2018) [in Russian] ISSN 2072-3172

7. A. Meneghetti, Pedagogia ontopsicologica (Psicologica Editrice, Roma, 2007)

8. ESU, 2018, Bologna with Student Eyes 2018, the Final Countdown. http://bit.ly/2Hm9QKB (accessed 20/11/2019).

9. European University Association (EUA), 2009, Improving Quality, Enhancing Creativity: Change Processes in European Higher Education Institutions. Final Report of the Quality Assurance for the Higher Education Change Agenda (QAHECA) Project. (Brussels, EUA). http://bit.ly/2S02Ndj (accessed 20/11/2019).

10. K. Robinson, Creative schools: the grassroots revolution that's transforming education (New York: Viking, 2015) 